\title{
Innovative Mode for Socialized Information Services of University Libraries
}

\author{
Qinhong MAO \\ JiangsuUniversity of Technology, Changzhou, 213001, China
}

\begin{abstract}
Electronic information technology has been widely applied to social life and production, driving the society forward. Libraries are also adopting electronic information technology. Socialized information services of university libraries are characterized by diversified and broad literatures as well as online resources. However, at present, socialized information services in China's university libraries are troubled by a few kinds of service and small service coverage. Based on analysis of problems mentioned above, this study proposes several innovative measures to promote mode innovation of socialized information services in university libraries.
\end{abstract}

KEYWORD: University library; socialized information service; network; literature

\section{CHARACTERISTICS OF SOCIALIZED INFORMATION SERVICES OF UNIVERSITY LIBRARIES}

\subsection{Diversification of Literature Resources}

The ever-developing network technology enables universities to establish digital libraries with much more digital literatures than ever. In the socialized information services of university libraries, there exists both traditional printed literature and digital literature [1]. These two kinds of literature resources rely on and complement each other. Literature sources also follow the trend of diversification.

\subsection{Various Sources of Literature Information}

Benefiting from digital library and cooperation of different libraries, socialized information services of university libraries are able to provide resources both from only one library and other libraries [2]. All these resources covering every discipline meet the diversified needs of different readers.

\subsection{Online Service}

University libraries now simultaneouslyprovide traditional manual service and remote service for the public. Therefore, the public can access resources via special database without time and space restrictions.

\section{CURRENT SOCIALIZED INFORMATION SERVICES OF UNIVERSITY LIBRARIES}

In spite of startup of socialized information services by domestic university libraries, many disagreements rise in this field. Besides, some factors are now affecting and restricting the development of the service [3]. Thus, socialized information services of university libraries are still faced with the following problems.

\subsection{Ambiguous Positioning}

University libraries usually serve as acdemic institutions to provide service for university teaching and researches. Regulations for Libraries of Regular Institutions of Higher Educationhad defined library as an important part of university teaching and researches, leading the library to exclude any other social unit except university[4]. Therefore, socialzed information services of university libraries have much concerns which functions as a blow to this service development to some extent.

\subsection{Limits and Poor Effect of Socialized Information Services}

Current socialized information services of university libraries put some limits on readers' identities, access time, type and mode of resource utilization et. al. Before, university libraries only serve teachers and students. After the socialized information service is 
put into operation, quantity of readers should be limited in order not to affect university teachers and students. Limits on readers' identities focus on degree, tile and recommendation [5]. Access time of socialized information service may be set during the summer and winter vacation. As for type of resource utilization, off-campus readers will be limited to utilize books, printed journals and digital literatures. In terms of the mode of utilization, the date limit and whether printed resources can be borrowed are also stipulated.

\subsection{Outdated Management Concept}

Management concept is crucial to the implementation of socialized information service to some extent. However, many library managers adhere to outdated management concept and the traditional collection-centered idea. As a consequence, the managers fail to fully realize the functions of information service. The construction and management of digital library does not be enhanced, either, resulting in poor collection, seiri, processing of network resources. In librarian beliefs, it is normal to serve teachers and students rather than social readers [6]. Thus, they negatively treat the socialized information service, with little initiatives. The outdated management concept severely impedes the opening-up of university libraries and implementation of socialized information service.

\section{MEASURES FOR MODE INNOVATION OF SOCIALIZED INFORMATION SERVICES}

As with the development of university libraries and socialized information services, university libraries will inevitably deepen its opening-up while actively seek cooperation for better service and improvement of their sustainable development.

\subsection{Service Expansion Oriented to Society}

In recent years, public libraries started socialized information services to provide social readers with kinds of information, such as National Library of China, Shanghai Library and Sun Yat-Sen Library of Guangdong Province. Learning about the public information demands viacooperation with medium and large enterprises, public libraries are able to offer special briefs and door-to-door service. However, university libraries fall behind the public libraries in this respect. In author's opinion, universitylibraries need to focus on their own tasks under current conditions. In addition, information service should be provided by university libraries for social readers without interference in serving the teachers and students.
Socialized information services of university libraries have to help with local economic construction. Due to significance of local economy on the development of university libraries, university libraries are supposed to cooperate with enterprises and scientific research institutions. In this way, the libraries will clearly master the information demands of the public in order to provide better service for social readers. University libraries should develop socialized information services with their own characteristics. Characteristic service is the key for library development, shown in literature contents and service mode et.al. In ethnic universities and colleges, there are lots of valued and characteristic literatures about minorities and some manuscripts of celebrities. For example, the library of Jishou University collects some manuscripts by Shen Congwen and objects used by him. In a word, to establish a well-developed digital library with remote information service for readers, university libraries need to take advantages of their own prominent characteristics and some referential characteristic resources.

Besides, socialized information service should include virtual reference, offering service through email, BBS, or such real-time service through QQ, MSN. If readers are given rights to choose the service according to their own preferences and conditions, university libraries will surely move up the service efficiency and quality.

\subsection{Mode Innovation and Diversified Service}

Mode innovation of the service is an important step for the reform of socialized information services of university libraries. To meet the demands of readers in the knowledge economy era, university libraries need reform the traditional service mode. For example, they can offer virtual reference, electronic literature delivery, novelty search and search \& translation services with multimedia technology on the bases of fast and convenient retrieval, browsing, replication and consultation. The traditional service mode should be changed from searching to tracking, passive to active and real to virtual. If the university libraries innovate their service modes based on readers' demands, readers will experience a convenient information service. Meanwhile, cultural quality of the public and economic construction will be improved with transmission of the information resources, ultimately pushing the development of university libraries forward.

\subsection{Market Segmentation and Stimulation of Potential Demand}

In addition to the readers who need the service, socialized information service need to discover some potential readers to expand the coverage and 
quantity of service recipient. Current socialized information services of university libraries mainly target the individuals and a few enterprises. Under the pattern of overall development of regional economy and rural-urban integration, there are some potential clients of information service such as local government and township enterprises. University libraries can provide these readers mentioned above with specific information service after determining service mode and content according to their needs.

\subsection{Regional Library Consortium}

Regional library consortium is formed via cooperation of university library, government, public library, and library of brother university to provide better socialized information service. In the consortium, cooperation of university and public libraries gives full play to the advantages of the libraries, such as resources, equipment and talent of university library and users, fixed places and readers of public library. Therefore, consortium is about to achieve a better effect of socialized information service.

Operation of the consortium requires a series of management regulations \& rules and uniform standard. Such documents may eliminate the restrictions of law principles for service sharing. Management of the consortium needs an independent agency which consists of main library leaders. The independent agency is obliged to carry out the implementation, management and supervision of information sharing. Additionally, for better information service, the consortium should consistently conduct research \& development, utilization, management and maintenance of the digitalization system. Besides, the consortium has to pay attention to the formation of a complete industry chain by dividing their work. Every member library participates in the whole resource integration for the improvement of service quality according to the market operation mode.

\subsection{Innovation of Operation Mechanism and Talent Advantage of University}

When involved in a specific research, university libraries can adopt the mode of consulting cooperate - a temporary team whichdeploys manpower and material resources for the particular task. This mode has three advantages: flexible organization mechanism, embedded service and extensive experts. Flexible organization mechanism means that a temporary team is formed by rules and procedures with dedicated working environment and good atmosphere. Since the mechanism brings the readers into team construction, tasks are directly and effectively assigned. Once any problems are found, this team will swiftly take measures to solve them.
Embedded service is characterized by clear goal and independence of the team. Thus, work efficiency will be undoubtedly increased. Extensive experts, the talent advantage of university, are introduced into the temporary team to improve the knowledge structure due to complicated problems of readers. With experts' help, the team is expected to think and solve problems in a deep and comprehensive manner. After the research is finished, the temporary team will be dismissed. Adopting this operation mechanism, university libraries are able to make full use of talent advantage. It is also possible to reduce the cost of human resources. Therefore, mode of consulting cooperate is a good mechanism for the operation of socialized information service.

\section{CONCLUSIONS}

At present with rapid social and economic development, information demands of social readers are also gradually increase. It is time for university libraries to truly recognize their important function in culture service system, public education and knowledge dispersion. Moreover, it is a show time for the socialized information service. University libraries must face the problems in this service mode. For problem settlement, university libraries need to strengthen their own construction while seek for cooperation. Information demands of readers will be satisfied by expanded service, innovative service mode and operation mechanism. After analyzing the existing problems in the current socialized information services of university libraries, this study proposes several suggestions for progress of this service and society.

\section{REFERENCES}

[1] Chen Xiuhua, Socialized Information Services of University libraries. Lantai World, 2014, (2): 117-118.

[2] Zhang Jing, On Practice and Development of Socialized Information Services of University libraries. Lantai World, 2014, (2): 146-147.

[3] Zhang Junhua, Study on Socialized Information Services of University Libraries Based on Regional Development Planning. Journal of Library Science, 2013, 35 (12):6971.

[4] Li Pei, Empirical Study on Socialized Information Services of University Libraries in Guangdong. Journal of Library Science, 2010, 32 (4): 77-80.

[5] Cheng Wenyan, Talking about the Knowledge Management Scheme for Social Information Services of University Libraries. Sic-Tech Information Development \& Economy, 2011, 21 (25): 81-82, 87.

[6] Qu Guanjun, Bao Haiyan, Yu shuxia, Study on the Literature Resources Development and Socialized Information Service of the Library of Ethnic Universities. Sic-Tech Information Development \& Economy, 2014, 24 (12): 22-24. 
